\title{
Nonstate Warfare: The Military Methods of Guerillas, Warlords, and Militias. By Stephen Biddle. Princeton, CT: Princeton University Press, April 2021.
}

Robert J. Bunker

C/O Futures, LLC

Follow this and additional works at: https://digitalcommons.usf.edu/jss

pp. $107-110$

\section{Recommended Citation}

Bunker, Robert J.. "Nonstate Warfare: The Military Methods of Guerillas, Warlords, and Militias. By Stephen Biddle. Princeton, CT: Princeton University Press, April 2021.." Journal of Strategic Security 14, no. 4 (2021) : 107-110.

DOI: https://doi.org/10.5038/1944-0472.14.4.1992

Available at: https://digitalcommons.usf.edu/jss/vol14/iss4/8

This Book Review is brought to you for free and open access by the Open Access Journals at Digital Commons @ University of South Florida. It has been accepted for inclusion in Journal of Strategic Security by an authorized editor of Digital Commons @ University of South Florida. For more information, please contact digitalcommons@usf.edu. 
Nonstate Warfare: The Military Methods of Guerillas, Warlords, and Militias. By Stephen Biddle. Princeton, CT: Princeton University Press, April 2021. 


\title{
Nonstate Warfare: The Military Methods of Guerillas, Warlords, and Militias. By Stephen Biddle. Princeton, CT: Princeton University Press, April 2021. ISBN: 978- 0-691-20751-3. Hardcover. 434 pages. \$35.0o
}

\author{
Review by Robert J. Bunker, PhD
}

Futures, LLC

The author of Nonstate Warfare, Stephen Biddle, is a professor of international and public affairs at Columbia University and an adjunct senior fellow for defense policy at the Council on Foreign Relations (CFR). He formerly held the Elihu Root chair in military studies at the U.S. Army War College Strategic Studies Institute (SSI), has extensive Department of Defense (DoD) policy experience, and is the author of Military Power: Explaining Victory and Defeat in Modern Battle (Princeton, 2004). The multi-year research study underpinning the book was financially supported by several non-governmental and U.S. governmental entities as well as a sizeable team of individuals who provided research, peer, and professional review support. This pedigree immediately places the book in the higher tier category of academic defense publications.

The focus of the work and its thesis are as follows:

to explore these military methods in detail, to describe more carefully the differences of degree that distinguish the real battlefield behavior of state and nonstate militaries, and to explain the variations one observes when doing so. The explanation I propose focuses on differences in the internal political makeup of different nonstate actors-especially their varying internal institutions and perceived stakes in the wars they fight-as central causes of their observed behavior. I contrast this political theory of nonstate behavior with common alternative views that focus on non-state material disadvantages or tribal culture, and I argue that internal politics, in interaction with the nature of available technology, offers a more successful explanation (p. xvi). 
The term 'these' refers to The Military Methods of Guerillas, Warlords, and Militias found in the subtitle of the book. These military methods are discussed in detail along a Fabian (Delaying)-Napoleonic (Battle) Spectrum that includes stealth, holding ground, dispersion, coercive strategic intent, and two forms of asymmetry-combatant (target lock) and front/rear (spatial dynamics) methods (Table 2.1; pp. 26-39 discussion). These methods, are in turn, modified by various actors ranked on the Fabian-Napoleonic spectrum (Figure 2.1; pp. 39-45 discussion) by means of their military behavior.

The book itself contains a list of figures, tables, and maps; a preface, ten chapters, an appendix, notes and an index. The chapters are divided into (1) Introduction; three chapters comprising a literature review and methodology with dependent variable, and theory section; (2) The Fallacy of Guerilla Warfare, (3) Materially Optimal Behavior, and (4) Politically Achievable Behavior; case studies spanning five chapters; (5) Hezbollah in the 2006 Lebanon Campaign, (6) The Jaish al Mahdi in Iraq, 2003-2008, (7) The Somali National Alliance in Somalia, 1992-94, (8) The ZNG (Croatian National Guard), HV (Croatian Ground Army), and SVK (Serbian Army of Krajina) in the Croatian Wars of Independence, 1991-95, (9) The Vietcong in the Second Indochina War, 1965-1968; and the final study section (10) Conclusions and Implications. The work has a very tight research design, an almost precision execution, is extensively referenced with hundreds of citations in the notes section (pp. 337-424), and contains a useful index. A bibliography would have been useful and larger font for the notes would have been appreciated but this does not detract from the study itself.

The most important components of Nonstate Warfare are its new theory development and policy implications, which may appear counterintuitive based on contemporary Department of Defense (DoD) perceptions. The new theory component utilizing military behavior (as a dependent variable) along the Fabian-Napoleonic spectrum is modified by actor choice (which is materially optimal behavior seeking) "using a rationalist causal logic with four independent variables: two that describe materiel (numerical imbalance, and technological sophistication), and two that describe internal politics (institutionalization and stakes)" (p. 46). The case study results can be found in Table 10.1 and discuss the independent variable values (materiel, tribal culture, and internal politics) and the 
theoretical predictions of the independent values along with the observed outcome (p. 295).

The 'so what' component of the book that distinguishes it from more solely academic efforts is the policy implications discussed by Biddle as they relate to (a) future opponent's military methods and (b) force structure and modernization. The initial implications are that state and non-state warfighting methods are overlapping (See Fig. 10.1; pp. 297-300 discussion) based on expected frequency of war-fighting methods trending. The resulting implications-in this instance, 'initial observations' offered by Biddle (p. 301) - for the US government and DoD is that of a 2020 capability which is mid-tier (general purpose; 'medium weight version of the legacy force') and which can respond to both low tech (Fabian; wearing down) and high tech (Napoleonic; conventional and precision targeting) threat forces (See Fig. 10.2; pp. 301-310).

Interestingly, befitting the academic elements of the work, implications for scholarship are also offered. They center on determinants for state and nonstate behaviors and the potentials for a "unified theory of state and nonstate war making" (p. 310) which spans interstate and civil war environments. The intent would be to remove subdiscipline stove piping and bring back interdisciplinary approaches to studying a complex realworld phenomenon. This makes sense in our present era of immense disruptive change and the challenges it is posing to the modern state form.

Both the blessing and the bane of the work is that it is "intellectually thick" in the writing and flow. It reads like a clinical IR/defense policy research study. While the author took pains (p. xviii) to write in natural language and relegate the technical aspects of the work to the appendix (which includes operationalizations, formulas, and spectrum scores), the reviewer's perception is that the reader still needs a graduate level education to properly comprehend and validate (or question) the methodology utilized in Biddle's tome. Also, the Vietnam case study utilized from 1965-1968 seems a bit temporally disassociated from the four others spanning the 1991-2008 historical cluster. That case study, however, could be considered a control group given the importance of the Vietcong, their paradigmatic status to the American counterinsurgency (COIN) experience, and the conduct of the conflict prior to the 'advent of precision firepower' (p. 263). 
In summation, the work has been lauded for its innovation and importance (as by Sir Lawrence Freedman) and does not disappoint in this respect. It delves into the challenges posed by non-state warfare for the US military and the liberal-democratic government to which it is subordinate. This is an area in which we have a rather dismal track record. While great power conflict is increasingly dominating our national security strategy and would seem to minimize the need for the relevance of such a work, the importance of COIN refuses to recede into the background given recent events in Afghanistan, the potential resurgence of Salafist-Jihadi groups, and ongoing Iranian-regime weaponization of Shia populations throughout the world. 